University of Nebraska - Lincoln

DigitalCommons@University of Nebraska - Lincoln

Papers in the Earth and Atmospheric Sciences

Earth and Atmospheric Sciences, Department

November 2000

\title{
Chemical and Biological Trends during Lake Evolution in Recently Deglaciated Terrain
}

\author{
Daniel R. Engstrom \\ St Croix Watershed Research Station, Science Museum of Minnesota, Marine on St Croix, Minnesota, \\ dre@smm.org \\ Sherilyn C. Fritz \\ University of Nebraska-Lincoln, sfritz2@unl.edu \\ James E. Almendinger \\ St Croix Watershed Research Station, Science Museum of Minnesota, Marine on St Croix, Minnesota \\ Stephen Juggins \\ University of Newcastle, Newcastle upon Tyne NE1 7RU, UK
}

Follow this and additional works at: https://digitalcommons.unl.edu/geosciencefacpub

Part of the Earth Sciences Commons

\footnotetext{
Engstrom, Daniel R.; Fritz, Sherilyn C.; Almendinger, James E.; and Juggins, Stephen, "Chemical and Biological Trends during Lake Evolution in Recently Deglaciated Terrain" (2000). Papers in the Earth and Atmospheric Sciences. 46.

https://digitalcommons.unl.edu/geosciencefacpub/46
}

This Article is brought to you for free and open access by the Earth and Atmospheric Sciences, Department of at DigitalCommons@University of Nebraska - Lincoln. It has been accepted for inclusion in Papers in the Earth and Atmospheric Sciences by an authorized administrator of DigitalCommons@University of Nebraska - Lincoln. 


\title{
Chemical and Biological Trends during Lake Evolution in Recently Deglaciated Terrain
}

\author{
Daniel R. Engstrom, ${ }^{1}$ Sherilyn C. Fritz, ${ }^{2}$ James E. Almendinger, ${ }^{1}$ and Stephen Juggins ${ }^{3}$ \\ ${ }^{1}$ St Croix Watershed Research Station, Science Museum of Minnesota, Marine on St Croix, Minnesota 55047, USA \\ ${ }^{2}$ Department of Geosciences and School of Biological Sciences, University of Nebraska-Lincoln, Lincoln, Nebraska 68588-0340, USA \\ ${ }^{3}$ Department of Geography, University of Newcastle, Newcastle upon Tyne NE1 7RU, UK \\ Corresponding author: Daniel R. Engstrom, email dengstrom@smm.org
}

\begin{abstract}
As newly formed landscapes evolve, physical and biological changes occur that are collectively known as primary succession. Although succession is a fundamental concept in ecology, it is poorly understood in the context of aquatic environments. The prevailing view is that lakes become more enriched in nutrients as they age, leading to increased biological production. Here we report the opposite pattern of lake development, observed from the water chemistry of lakes that formed at various times within the past 10,000 years during glacial retreat at Glacier Bay, Alaska. The lakes have grown more dilute and acidic with time, accumulated dissolved organic carbon and undergone a transient rise in nitrogen concentration, all as a result of successional changes in surrounding vegetation and soils. Similar trends are evident from fossil diatom stratigraphy of lake sediment cores. These results demonstrate a tight hydrologic coupling between terrestrial and aquatic environments during the colonization of newly deglaciated landscapes, and provide a conceptual basis for mechanisms of primary succession in boreal lake ecosystems.
\end{abstract}

\section{एோவாோ}

Eutrophication is often described as an acceleration of the natural ageing process of lakes, based on an early ecological model in which lakes become more productive as they age. ${ }^{1}$ This model of lake development, which originated with efforts to classify European lakes by trophic status, ${ }^{2-4}$ persists to the present day ${ }^{5}$ despite paleolimnological evidence that many temperate-region lakes follow the opposite trend and become more dilute and unproductive over time. ${ }^{6-10}$ Although sedimentary records have advanced our understanding of lake development beyond the simple eutrophication model, the patterns and controls of long-term limnological change remain poorly understood, because direct observation is impossible at these timescales and because few regions exist where lakes can be studied immediately following formation. In glaciated landscapes, where most of the world's lakes occur, the period following ice recession saw dramatic changes in terrestrial vegetation, soils and hydrology. Yet we know little of how newly formed glacial lakes respond to these environmental forces, whether there are common pathways of development within a given geographical region, or how underlying differences in geology and climate affect the direction and rate of limnological change. Moreover, it is unclear whether changes to lakes ("lake trajectories") are in fact driven by ecological processes set in motion by glacial retreat or whether they represent the direct forcing of a rapidly changing climate. ${ }^{11}$

To explore more directly the environmental forces controlling lake development, we studied a suite of recently formed lakes in Glacier Bay National Park, Alaska, where more than 1,000 years of late Holocene ice advance and retreat has created lake-studded glacial forelands, among the most extensive found anywhere in the world. ${ }^{12}$ We compare limnological conditions among 33 lakes of differing ages, and infer patterns of limnological change by assuming that the sequence represents lakes at different developmental stages. This approach has been widely used to model long-term developmental processes in terrestrial systems, as exemplified by the classic studies of primary succession at Glacier Bay. ${ }^{13-17}$ Because a spatial array of modern sites may not fully describe temporal patterns exhibited by a single site over its history, ${ }^{18-20}$ we also reconstruct limnological trends from sediment cores from individual lakes and compare these trends with those exhibited by the chronosequence. Lake histories are reconstructed from fossil diatoms by using transfer functions developed from the relationship between modern diatom assemblages and environmental variables in the Glacier Bay lakes.

\section{The Glacier Bay chronosequence}

The studied lakes were created by a sequence of glacial advances and retreats dating from this century back to late Wisconsin time (14,000 years ago). All occupy small primary catchments receiving no drainage from other lakes or major streams; most are small (3-16 ha) and moderately deep (maximum depth, 3-18 m). Twenty-one were formed by catastrophic recession of late Holocene ice from low-elevation forelands along the Glacier Bay fjord, and range in age from 10 to 220 years (Figure 1). Twelve additional lakes are located on glacial forelands along the outer coast (350-2,700 years) and on late Wisconsin surfaces on Pleasant Island (13,000 years). Catchment vegetation grades from a sparse cover of early colonizers (Epilobium, Dryas, Salix) at the youngest sites ( $<50$ years old) to dense shrub thickets of Sitka alder (Alnus sinuata), closed forests of Sitka spruce (Picea sitchensis) and western hemlock (Tsuga heterophylla), and ultimately open peatlands on the oldest surfaces $(>1,000$ years old). The Glacier Bay region has a maritime climate with small annual temperature variations, frequent cloud cover, and heavy precipitation. ${ }^{21,22}$

Each lake in the chronosequence was sampled for water chemistry a minimum of three times over a three-year period to assess seasonal and interannual variability; these data are supplemented for 17 sites by collections from three previous years. The lakes exhibit a wide range of ionic strengths (ion sums, 0.1-6.2 mequiv. $\mathrm{l}^{-}$ ${ }^{1}$ ); the more concentrated lakes (ion sums, $>1$ mequiv. ${ }^{-1}$ ) are dominated by $\mathrm{Ca}^{2+}$ and $\mathrm{HCO}_{3}^{-}$ions, whereas the more dilute lakes have $\mathrm{Na}^{+}, \mathrm{Cl}^{-}$, and organic anions in greater proportion. Concentrations of chlorophyll $\alpha$ are below 1.2 parts per billion (p.p.b.; median, 0.3 p.p.b.), total phosphorus (TP) less than 10.5 p.p.b. (median, 5.5 p.p.b.), and total nitrogen (TN) less than 400 p.p.b. (median, 215 p.p.b.), indicating oligotrophic conditions throughout the chronosequence. 


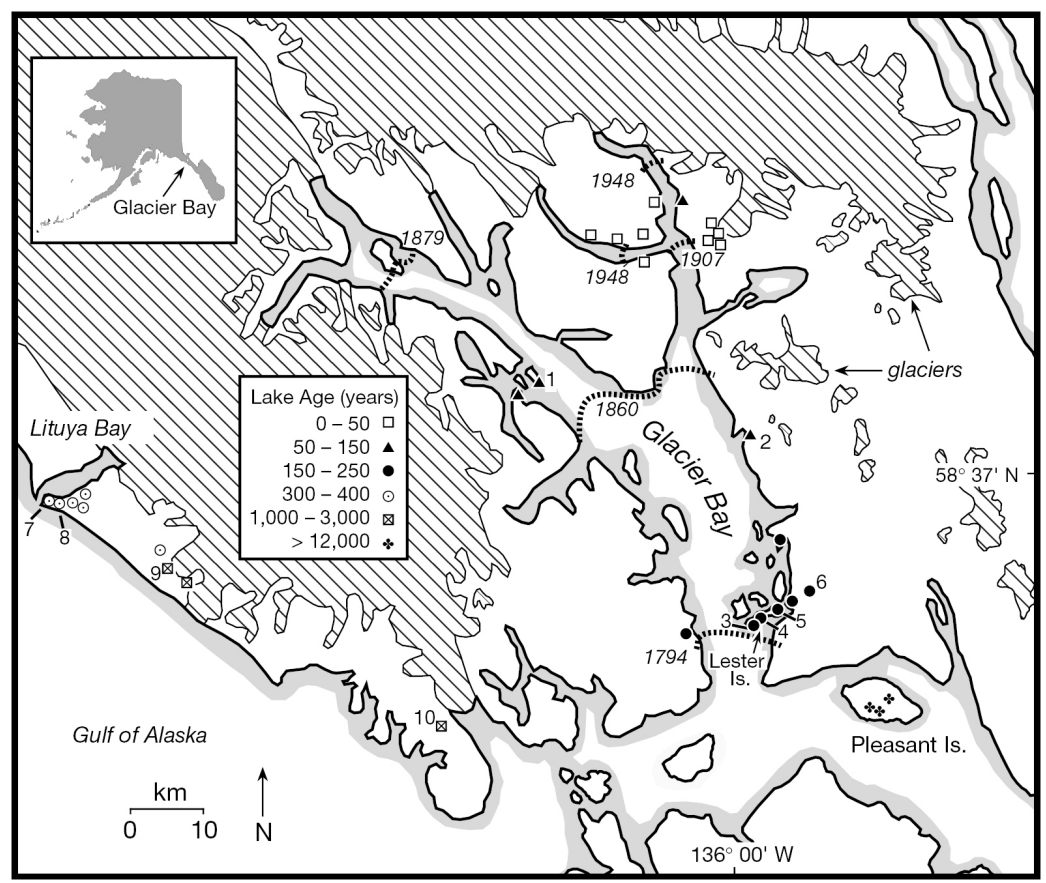

Figure 1. A chronosequence of lakes in the Glacier Bay region of southeastern Alaska. Late Holocene ice margins are marked by dated isochrons; numbered lakes have core trajectories shown in Figure 3. Lake age along the Glacier Bay fjord is generally contemporaneous with the date of surface deglaciation, which is known from the observations of early explorers and scientists, tree-ring chronologies, and photographic records. ${ }^{16}$ The ages of lakes at Lituya Bay are based on ${ }^{14} \mathrm{C}$ dating of morainal surfaces, ${ }^{40}$ while the ages of older sites along the outer coast and on Pleasant Island were established by ${ }^{14} \mathrm{C}$ dating of basal sediments from cores obtained in this study (Brady, $1230 \pm 50$ years bp; Dagelet, $1080 \pm 60$ years bp; LaPerouse, $2690 \pm 60$ years bp) and from Engstrom et al. ${ }^{41}$
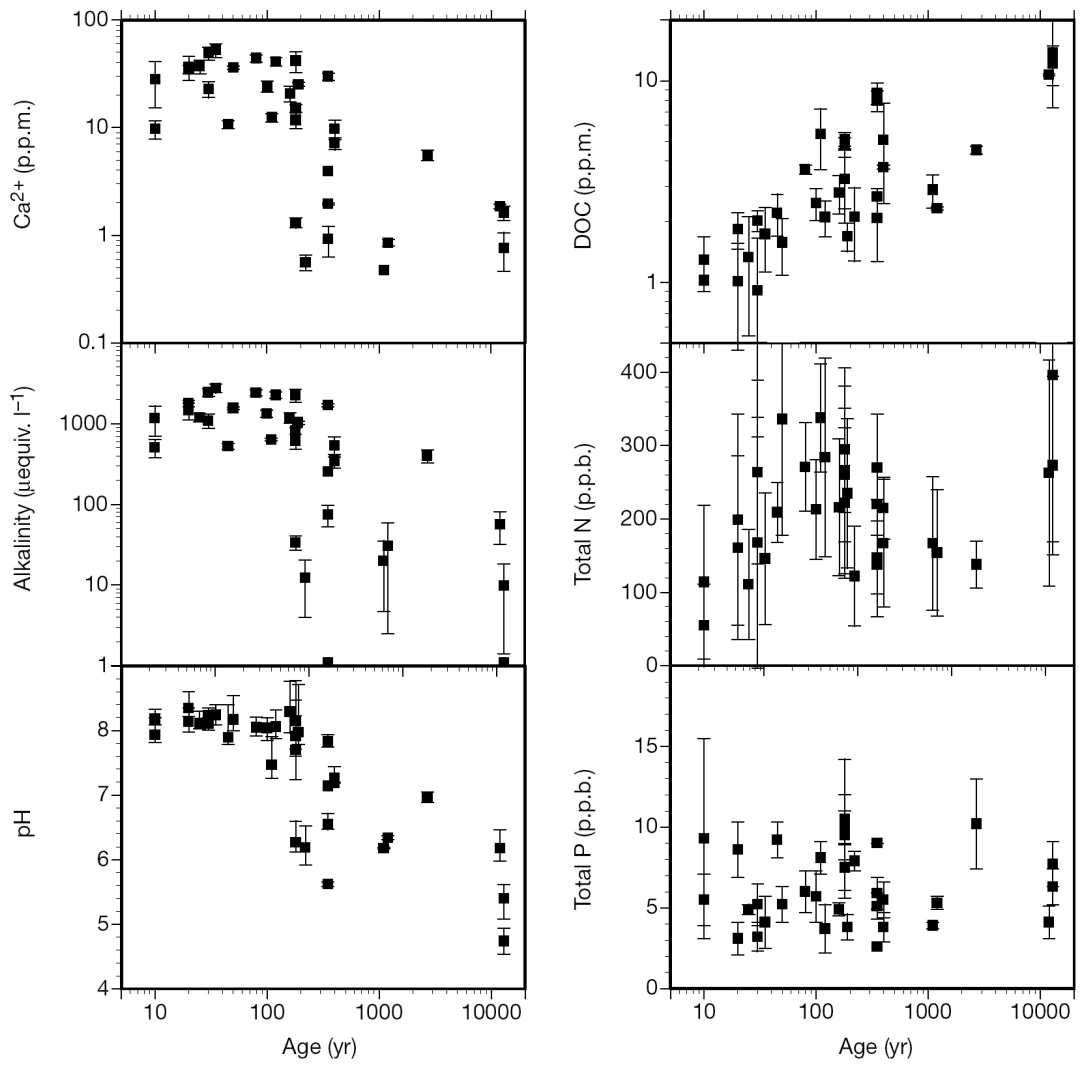

Figure 2. Relationship between lake age and mean values of selected water-chemistry variables in the Glacier Bay chronosequence. Error bars ( \pm 1 s.d.) depict variation among sampling dates. Lakes were sampled at a depth of $1 \mathrm{~m}$ with a Kemmerer bottle; pH was measured in the field; alkalinity (Gran titration) and apparent color were measured within $12 \mathrm{~h}$ of sample collection. Samples were filtered (at $0.45 \mu \mathrm{m}$ ) and frozen for laboratory analysis of DOC (carbon analyzer) and major anions (ion chromatography). Unfiltered samples were analyzed for TP and TN (colorimetric methods) and major cations (direct current plasma-atomic emission spectrometry) TN samples were acidified. Chlorophyll $\alpha$ was measured by high-performance liquid chromatography on samples filtered in the field. 
Most limnological parameters exhibit clear trends with lake age. All major cations and all anions except $\mathrm{Cl}^{-}$show declining concentrations along the chronosequence of sites from youngest to oldest. The general trend is illustrated here (Figure 2) by the results for $\mathrm{Ca}^{2+}$ and alkalinity. While there is substantial scatter in the data for any particular time slice, there are clearly no old lakes with high $\mathrm{Ca}^{2+}$ or alkalinity, and conversely no young lakes with low $\mathrm{Ca}^{2+}$ or alkalinity. Trends are also evident in $\mathrm{pH}$, dissolved organic carbon (DOC) and TN. Surface-water $\mathrm{pH}$ is uniformly high (> 8.0) for lakes less than 200 years old, but shows a declining pattern with lake age among older sites (Figure 2). This $\mathrm{pH}$ trend reflects the greater carbonate buffering of the younger lakes (high alkalinities) and the increasing concentration of organic acids (as illustrated by DOC) in the older lakes. Total $\mathrm{N}$ also increases with lake age, but only for the first one to two centuries, declining thereafter except for the three oldest lakes on Pleasant Island. Total-P concentrations, on the other hand, show no clear trend with age since deglaciation.

An analysis of diatoms in surface sediments from the 33 lakes suggests that changes in water chemistry over time drive changes in biological communities. Detrended canonical correspondence analysis (DCCA) of the diatom assemblages and associated waterchemistry data ${ }^{23}$ show that the major axis of variation in the diatom data is closely aligned with $\mathrm{pH}$ and DOC, while the second axis is most strongly correlated with TN ( Figure 3 inset). Axis 3 (not shown) reflects the influence of sea-spray $\left(\mathrm{Na}^{+}, \mathrm{Cl}^{-}\right)$. Diatom assemblages in lakes of similar age are of similar composition: the youngest lakes ( $<50$ years) cluster in the lower right of the diagram (high $\mathrm{pH}$, low DOC, low TN), lakes of intermediate age (50250 years) generally cluster in the upper right (high $\mathrm{pH}$, low DOC, medium to high TN), and the older lakes (>300 years) cluster on the left side of the first axis (lower $\mathrm{pH}$, high DOC, medium TN).

\section{Sediment records of lake trajectories}

To corroborate the pattern of limnological development suggested by the chronosequence, we analyzed fossil diatoms in sediment cores from 10 individual lakes ranging in age from approximately 100 to 1,000 years. These cores were collected from the deepest region of each lake, sectioned in the field at $0.5-1.0 \mathrm{~cm}$ intervals, and dated by ${ }^{210} \mathrm{~Pb}$. Limnological trends are summarized by projecting the core diatom assemblages onto the DCCA biplot of the modern samples (Figure 3, main figure). Most lakes show a net negative trajectory along axis 1 (decreasing $\mathrm{pH}$, increasing DOC), although the pattern varies among lakes. The older sites in the outer coast region (Paps, Harbor Point, Dagelet, Brady) cluster together in the lower left of the plot, whereas the younger sites along the Glacier Bay fjord (Spokane Cove, Blue Mouse, Lester1, Lester-2, Lester-3), with the exception of Bartlett Lake, cluster in the upper right of the plot. The splitting of the trajectories into two groups suggests that the outer coast sites started at a different point along the gradient of the first axis than did the other lakes. The younger group of lakes also shows an early positive movement along the second axis (increasing TN), whereas the older group of lakes shows the opposite pattern or no net trend.

The core data thus confirm the main trend of lake development suggested by the modern chronosequence: a progressive loss of $\mathrm{pH}$, alkalinity, and base cations, and a corresponding increase in DOC. This trend is clearly manifest in all but three of the youngest lakes (Blue Mouse, Spokane, Lester-3), a pattern consistent with chronosequence results showing $\mathrm{pH}$ and alkalinity declines beginning some

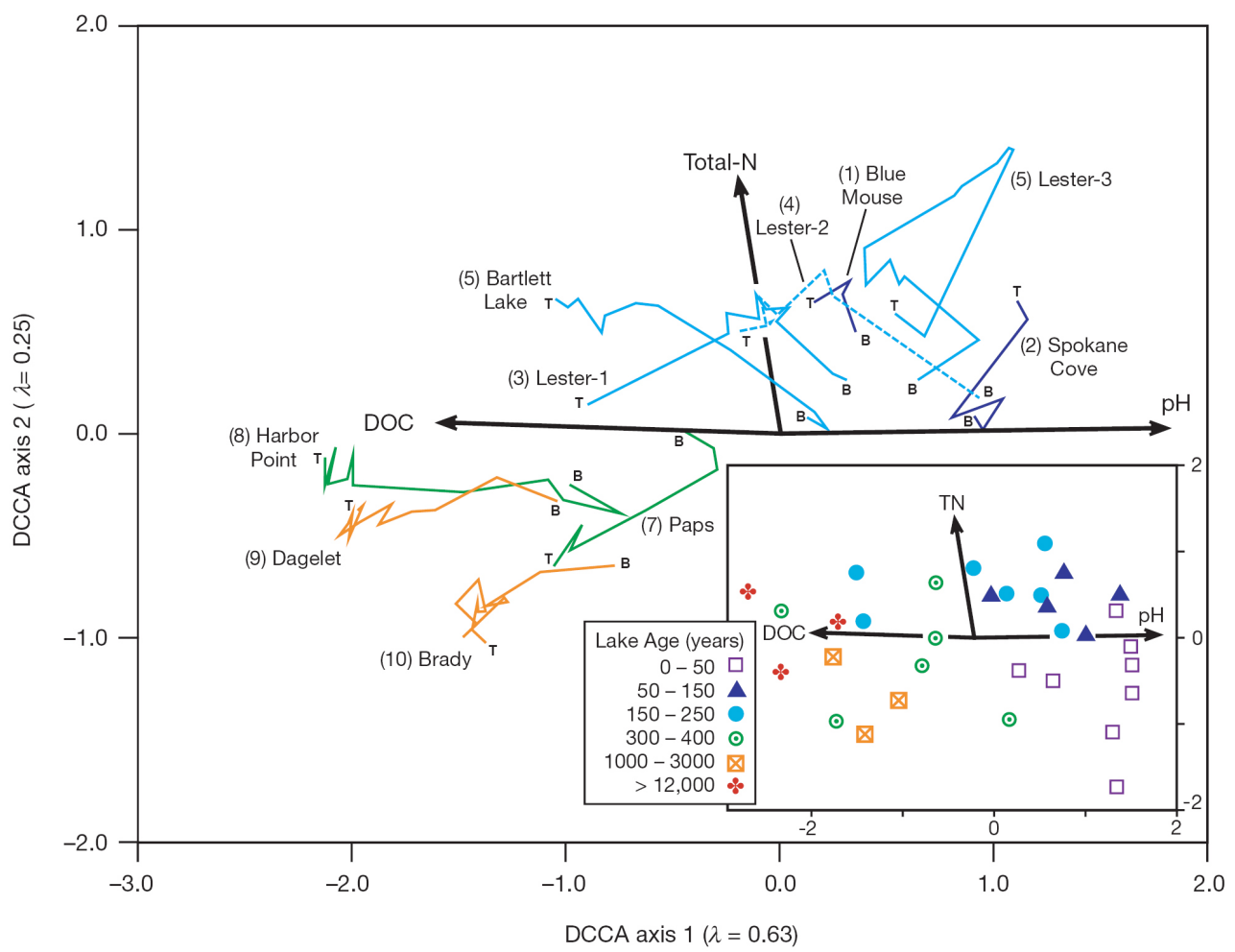

Figure 3. Detrended canonical correspondence analysis of modern and fossil diatom assemblages from the chronosequence lakes. Inset, ordination of modern diatom assemblages (from surface sediments) and associated water-chemistry data; water-chemistry variables were chosen by forward selection (a stepwise addition based on explained variance). The arrows depict the direction of increase and maximum variation of the measured environmental variables; other significant variables (not shown) include $\mathrm{Na}^{+}, \mathrm{Cl}^{-}, \mathrm{SO}_{4}{ }^{2-}$, and total-Al. Lakes plotting close to one another have similar diatom composition. Main figure, the time-trajectories from 10 sediment cores (B, bottom; $\mathrm{T}$, top) were projected onto the biplot by adding the core assemblages to the analysis as passive samples; numbers on lake trajectories correspond to map localities in Figure 1. Diatoms were extracted and identified following standard procedures; a minimum of 500 individual diatoms in surface samples and 400 in core samples were counted. A final dataset of 223 taxa, which included only those with $\geq 0.5 \%$ relative abundance in at least one sample from two or more lakes, was used for statistical analysis. Chemical variables that were positively skewed were $\log _{10}$ or square-root transformed before statistical analysis. 
200 years after deglaciation. However, the core trajectories indicate that the patterns of change for TN are highly variable and that the $\mathrm{TN}$ trend observed in the modern chronosequence cannot be generalized, even to this relatively small geographical region.

\section{Mechanisms of limnological change}

The effects of vegetational succession, soil development and hydrologic change, which are all potential agents of lake development, can be inferred by correlation of the limnological trends with those occurring during primary succession in the terrestrial system. In the case of soil development, we have a well documented picture of carbonate loss, $\mathrm{pH}$ decline, and carbon and nitrogen increase during the first century of terrestrial succession at Glacier Bay. ${ }^{24-26}$ Thus the weathering of soluble minerals from upper soil horizons may be partially responsible for lakes becoming more dilute and acidic over time, while the steady accretion of soil organic matter probably contributes to a greater flux of organic acids (DOC) that stain the waters of older lakes. ${ }^{27-29}$

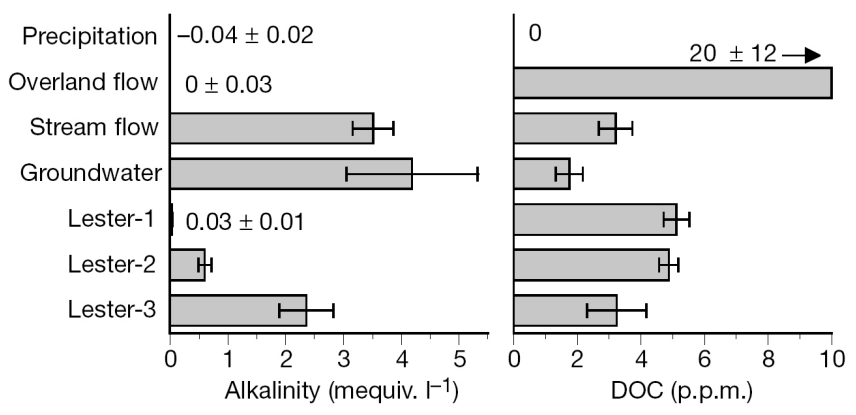

Figure 4. Water chemistry of three Lester Island lakes and their hydrologic sources. Precipitation was sampled monthly by bulk collector over three years; concentrations are volume-weighted means. Stream flows were monitored continuously over a 3-year period by automated stage recorders and V-notched weirs. Groundwater head gradients were measured in littoral areas along the shoreline of each lake with a hydraulic potentiomanometer (mini-piezometer). ${ }^{42}$ Stream and groundwater chemistry was sampled a total of 3-5 times; values represent combined means from Lester-2 and Lester 3 (Lester-1 lacks inflows); error bars, \pm 1 s.d. Overland flow was sampled from temporary pools and forest hollows on Lester Island and in the Bartlett Cover area; values shown are means of 16 collections.
However, soil weathering alone is insufficient to explain the timing of dilution of lake waters in the chronosequence. Lake $\mathrm{Ca}^{2+}$ and $\mathrm{pH}$ do not decline appreciably over the same period of time that initial soil leaching is thought to occur (0-100 years). Furthermore, while surficial catchment drainage may lose ionic strength because of soil weathering, ground water at depth should be relatively unaffected by these changes. Lakes receiving even a moderate load of dissolved solids from sub-surface flow should not respond to terrestrial succession unless groundwater inputs are reduced in the process. That essentially all of the older sites along the outer coast and on Pleasant Island (most in carbonate-rich terrain) are dilute and at least somewhat acidic implies that groundwater inputs to lakes eventually decrease, either in volume or in concentration.

The most likely cause for a decrease in groundwater flux is a long-term decline in hydrologic recharge associated with soil development. Hardened soil horizons (organic-sesquioxide cemented hardpans) and thick accumulations of peat, which begin forming several hundred years after disturbance (by glaciation or windstorm in southeastern Alaska, gradually inhibit internal soil drainage and increase surface runoff. ${ }^{26,30,31}$ This process should ultimately lower groundwater tables and reduce groundwater discharge to lakes and streams. ${ }^{32}$ Surface runoff (either overland flow or interflow) coursing through peat or weathered soil horizons would bear a much smaller load of dissolved solids and higher concentrations of DOC than the ground water it replaced, and lakes receiving these inputs would gradually become more dilute and acidic.

The development of nitrogen-fixing alder thickets that cause the accretion of soil nitrogen during the middle stages of terrestrial succession is the likely driver for the rise and subsequent decline in lake-water TN depicted in the chronosequence and in core trajectories of younger sites along the Glacier Bay fjord..$^{33}$ Conversely, the absence of an alder phase in the vegetational development of the outer coast is probably the reason that core trajectories of older lakes do not show this transient rise in nitrogen. Because late Holocene ice advances along the outer coast were of relatively limited extent and deglaciated surfaces were always near spruce seed sources, alder was probably never a significant component of the vegetation. ${ }^{18-20}$ Without alder and the associated nitrogen fixation in soils, older sites along the outer coast did not receive the early pulse of lakewater TN that is recorded by younger lakes in upper Glacier Bay.

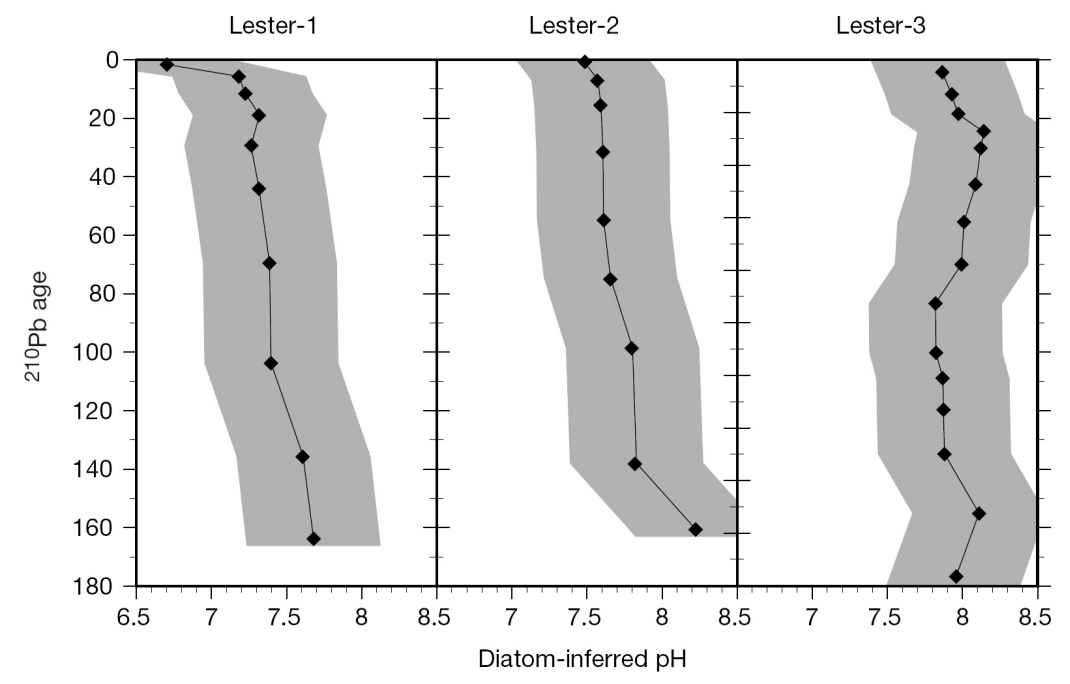

Figure 5. Core trajectories of three hydrologic study lakes on Lester Island. The $\mathrm{pH}$ trends were reconstructed from fossil diatom assemblages by using a weighted averaging transfer function. ${ }^{43}$ The shaded regions represent the root mean square error of prediction $(0.44 \mathrm{pH}$ units), a robust estimate of the predictive error of the transfer function derived by comparing measured $\mathrm{pH}$ and diatom-inferred $\mathrm{pH}$ for the suite of modern Glacier Bay lakes under cross-validation. The $\mathrm{pH}$ declines in Lester-1 $(1.0)$ and Lester-2 $(0.8)$ are statistically significant $(P<0.001)$ while the pH change in Lester-3 is not $(P=0.685)$; significance was assessed using linear regression with a restricted Monte Carlo permutation test appropriate for time-series. ${ }^{44}$ Ages (years before present) were determined by ${ }^{210} \mathrm{~Pb}$ dating. 


\section{Geological and hydrologic variability}

Although the stratigraphic analyses indicate that a decline in $\mathrm{pH}$ over time is a universal trend in our data set, the magnitude and timing of $\mathrm{pH}$ change differs, even among lakes of similar age (Figure 3, main figure). This variability in lake development is likewise reflected in the scatter of modern lake chemistries surrounding the main trends of the chronosequence (Figure 2). Most solutes show substantial variability among lakes of similar age, while certain sites (for example, Bartlett Lake) are consistent outliers for all ions. In addition to common pathways of lake development, core trajectories and chronosequence results illustrate the individual nature of lake development and its regulation by local factors.

We attribute most of the variability among lake trajectories to differences in hydrologic setting rather than differences in catchment lithology. Because the bedrock geology of Glacier Bay National Park is highly varied, ${ }^{34}$ we initially expected that lake chemistry might vary with localized differences in carbonate content of glacial till. However, we found no discernible relationship between the chemistry of the 11 youngest lakes ( $<100$ years) in the chronosequence and the carbonate content of unweathered soil samples from their catchments. ${ }^{35}$ This point is well illustrated by three hydrologic study sites on Lester Island, which show considerable variability in lake chemistry, even though they are of the same age (200 years), on similar geological substrate, at the same elevation, and in the same stage of vegetational succession. Lake-water alkalinity ranges from 0.03 mequiv. $1^{-1}$ in Lester- 1 to 2.36 mequiv. $1^{-1}$ in Lester-3, yet the percentage of carbonate in soil parent material $(\leq 62.5 \mu \mathrm{m}$ fraction) from their catchments is very similar (averaging $4-6 \%$ ).

Differences among the three lakes in their water sources rather than geological substrate account for their present-day differences in chemistry. All of the lakes receive direct precipitation and also some shallow sub-surface flow from the upper soil horizons directly beneath the organic layer (hereafter called overland flow). However, neither precipitation nor overland flow contains significant amounts of alkalinity (Figure 4), as the upper $50 \mathrm{~cm}$ or so of mineral soil on Lester Island is leached of carbonate. Thus the source of the alkalinity must be deeper groundwater flow, which either seeps directly into the lakes or enters them via streamflow. Annual loading of alkalinity via inlet streams ranges from 0 kequiv. in Lester-1 (no stream inflow) to 169 kequiv. in Lester2 and 302 kequiv. in Lester-3. These inputs are directly proportional to the range of alkalinities in the three lakes (Figure 4), as are the proportions of lake margin along which positive groundwater head-gradients were measured $(0 \%$ in Lester- $1,8 \%$ in Lester-2, and $45 \%$ in Lester-3). Because most groundwater flow in and out of lakes tends to occur near the lake margin, ${ }^{36}$ the length of shoreline with positive head gradient provides a qualitative measure of groundwater in-seepage. Thus the low alkalinity of Lester1 , as well as its high DOC concentration, results from the fact that it is fed exclusively by overland flow (low alkalinity, high DOC) and direct precipitation (low alkalinity, low DOC). By contrast, the hydrologic budget of high-alkalinity Lester-3 is dominated by stream and groundwater inflows (high alkalinity, low DOC), while Lester-2 is intermediate with respect to both lake chemistry and water sources (Figure 4).

In addition to explaining some of the scatter in the chronosequence data, these hydrologic observations provide a basis for understanding the different $\mathrm{pH}$ trajectories of the three Lester Island lakes. Using these hydrologic data, we predicted, a priori, that the magnitude of $\mathrm{pH}$ decline over the past 200 years should be greatest in Lester-1 and least in Lester-3. This prediction follows from the two suggested mechanisms for alkalinity loss: (1) a relatively rapid leaching of carbonates and other soluble minerals from surface soils, and (2) a relatively slow replacement of groundwater inflow by overland runoff caused by a gradual cementing of deeper soil horizons. The first of these processes is effectively completed within the first 100 years of deglaciation, whereas the second re- quires several centuries to become manifest. ${ }^{24-26,30}$ Hence, Lester-1 with little or no groundwater inflow should be most affected by the first process and quickly lose most of its buffering capacity, while Lester-3 with its substantial groundwater supply should show little change within its 200-year life span. Indeed, this is what we found in $\mathrm{pH}$ reconstructions from stratigraphic diatom assemblages (Figure 5): no net change in the $\mathrm{pH}$ of Lester-3, and statistically significant $\mathrm{pH}$ declines of 0.8 in Lester-2, and 1.0 in Lester-1 $(P<0.001)$. The reconstructions also suggest that Lester2 and Lester-3 were of approximately equal $\mathrm{pH}$ at the time formation, whereas Lester-1 has always been more dilute.

\section{Conclusions}

Our comparison of limnological trends, inferred from a chronosequence of lakes and reconstructed from sediment cores, indicates that progressive changes in major-ion chemistry are widespread across broad geographical regions. Patterns of nutrient change, however, are variable over relatively small spatial scales. Even among the more universal trends (decreasing $\mathrm{pH}$ ), local factors-particularly those related to hydrology-control the initial starting point as well as the rate and magnitude of change. Despite these underlying differences, the Glacier Bay results indicate that lakes may indeed age in a directional manner, driven largely by ecological forces that are set in motion with glacial retreat. Limnological change in the Glacier Bay region appears to be linked biogeochemically to the well studied process of primary terrestrial succession. The rapid re-vegetation of the newly deglaciated landscape $\mathrm{e}^{18-20}$ and associated changes in the soil-carbonate leaching, nitrogen fixation, humus build-up, and hardpan formation ${ }^{24-26,30}$-alter the flux of base cations, DOC, and nitrogen to downstream lakes, ultimately changing the biological components of the system, including algal communities, ${ }^{37}$ zooplankton, ${ }^{38,39}$ and higher aquatic plants. ${ }^{35}$ Clearly, the traditional model of progressive eutrophication over time does not apply to the Glacier Bay study lakes. The cool, moist climate of Alaska's temperate rainforests offers an optimal setting for the soil changes embodied in this model of lake development. However, similar conditions exist throughout the boreal forest regions of North America, Europe, and Asia, and so the patterns of limnological change found for Glacier Bay may thus apply to many of the lakes created by continental glaciation.

\section{Acknowledgments}

We thank B. A. Coffin, J. A. Janssens, M. G. Noble, G. O. Seltzer, E. B. Swain, and H. E. Wright for assistance in the field; Gustavus residents H. Burd, M. Hervin, R. Howe, and G. Streveler for their help; and NPS and USGS staff at Glacier Bay National Park for logistical support. This work was supported by the late D. B. Lawrence and by the National Science Foundation Ecology Program.

\section{References}

1. Rodhe, W. in Eutrophication: Causes, Consequences, Correctives (ed. Hutchinson, G. E.) 50-64 (National Academy of Sciences, Washington DC, 1969).

2. Pearsall, W. H. The development of vegetation in the English Lakes, considered in relation to the general evolution of glacial lakes and rock basins. Proc. R. Soc. Lond. B 92, 259-284 (1921).

3. Naumann, E. Grundzüge der regionalen Limnologie. Binnengewässer 11, 1-176 (1932).

4. Thienemann, A. Tropische Seen und Seetyplehre. Arch. Hydrobiol. 9, 205-231 (1931).

5. Carpenter, S. J., et al. Nonpoint Pollution of Surface Waters by Phosphorus and Nitrogen (Ecological Society of America, Washington DC, 1998 ). 
6. Whitehead, D. R., Charles, D. F., Jackson, S. T., Smol, J. P., and Engstrom, D. R. The developmental history of Adirondack (N.Y.) lakes. J. Paleolimnol. 2, 185-206 (1989).

7. Ford, M. S. A 10,000-yr history of natural ecosystem acidification. Ecol. Monogr. 60, 57-89 ( 1990).

8. Korhola, A. A., and Tikkanen, M. J. Holocene development and early extreme acidification in a small hilltop lake in southern Finland. Boreas 20, 333-356 (1991).

9. Renberg, I., Korsman, T., and Anderson, N. J. A temporal perspective of lake acidification in Sweden. Ambio 22, 264-271 (1993).

10. Battarbee, R. W., Charles, D. F., Dixit, S. S., and Renberg, I. in The Diatoms: Applications for the Environmental and Earth Sciences (eds Stoermer, E. F., and Smol, J. P.) 85-127 (Cambridge Univ. Press, Cambridge, 1999).

11. Birks, H. H., Battarbee, R. W., and Birks, H. J. B. The development of the aquatic ecosystem at Kråkenes Lake, western Norway, during the late-glacial and early-Holocene-a synthesis. J. Paleolimnol. 23, 91- 114 (2000).

12. Matthews, J. A. The Ecology of Recently Deglaciated Terrain (Cambridge Univ. Press, Cambridge, 1992).

13. Cooper, W. S. The recent ecological history of Glacier Bay, Alaska: II. The present vegetation cycle. Ecology 4, 223-246 (1923).

14. Cooper, W. S. A third expedition to Glacier Bay, Alaska. Ecology 12, 61-95 (1931).

15. Lawrence, D. B. Recent glacier history of Glacier Bay, Alaska and development of vegetation on deglaciated terrain with special reference to the importance of alder in the succession. Yb. Am. Phil. Soc. 1950, 175-176 (1951).

16. Lawrence, D. B. Glaciers and vegetation in southeastern Alaska. Am. Sci. 46, 89-122 (1958).

17. Reiners, W. A., Worley, I. A., and Lawrence, D. B. Plant diversity in a chronosequence at Glacier Bay, Alaska. Ecology 52, 55- 69 (1971).

18. Chapin, F. S., Walker, L. R., Fastie, C. L., and Sharman, L. C. Mechanisms of primary succession following deglaciation at Glacier Bay, Alaska. J. Ecol. 64, 149-175 (1994).

19. Chapin, F. S., Fastie, C. L., Walker, L. R., and Sharman, L. C. in Proc. Third Glacier Bay Sci. Symp. 1993 (ed. Engstrom, D. R.) 96-100 (National Park Service, Anchorage, 1995).

20. Fastie, C. L. Causes and ecosystem consequences of multiple successional pathways of primary succession at Glacier Bay, Alaska. Ecology 76, 1899-1916 (1995).

21. Brower, W. A. Jr , Diaz, H. F., Prechtel, A. S., Searaby, H. W., and Wise, J. L. Climatic Atlas of the Outer Continental Shelf Waters and Coastal Regions of Alaska Vol. 1, Gulf of Alaska (Environmental Information and Data Center, University of Alaska, Anchorage, 1977).

22. Hunter, L. E., and Powell, R. D. in Proc. Third Glacier Bay Sci. Symp. 1993 (ed. Engstrom, D. R.) 46-54 (National Park Service, Anchorage, 1995).

23. ter Braak, C. J. F. Canonical correspondence analysis: a new eigenvector method for multivariate direct gradient analysis. Ecology 67, $1167-1179$ (1986).

24. Crocker, R. L., and Major, J. Soil development in relation to vegetation and surface age at Glacier Bay, Alaska. J. Ecol. 43, 427448 ( 1955).

25. Ugolini, F. C. in Soil Development and Ecological Succession in a Deglaciated Area of Muir Inlet, Southeast Alaska (ed. Mirsky, A.)
29- 72 (Institute of Polar Studies, Ohio State University, Columbus, 1966).

26. Bormann, B. T., and Sidle, R. C. Changes in productivity and distribution of nutrients in a chronosequence at Glacier Bay National Park, Alaska. J. Ecol. 78, 561- 578 (1990).

27. Cronan, C. S., and Aiken, G. R. Chemistry and transport of soluble humic substances in forested watersheds of the Adirondack Park, New York. Geochim. Cosmochim. Acta 49, 1697- 1705 (1985).

28. Engstrom, D. R. Influence of vegetation and hydrology on the humus budgets of Labrador lakes. Can. J. Fish. Aquat. Sci. 44, 1306- 1314 (1987).

29. Rasmussen, J. B., Godbout, L., and Schallenberg, M. The humic content of lake water and its relationship to watershed and lake morphometry. Limnol. Oceanogr. 34, 1336-1343 (1989).

30. Ugolini, F. C., and Mann, D. H. Biopedological origin of peatlands in South East Alaska. Nature 281 , 366-368 (1979).

31. Noble, M. G., Lawrence, D. B., and Streveler, G. P. Sphagnum invasion beneath an evergreen forest canopy in southeastern Alaska. Bryologist 87, $119-127$ (1984).

32. Almendinger, J. E. in Proc. Second Glacier Bay Sci. Symp. (eds Milner, A. M., and Wood, J. D. Jr) 133-135 (National Park Service, Anchorage, Alaska, 1990).

33. Goldman, C. R. The contribution of alder trees (Alnus tenuifolia) to the primary productivity of Castle Lake, California. Ecology $\mathbf{4 2}$, 282-288 (1961).

34. Brew, D. A., et al. Mineral resources of Glacier Bay National Monument wilderness study area, Alaska. US Geol. Surv. Open-file Rep. 78-494 , 1-659 (1978).

35. Engstrom, D. R., and Fritz, S. C. in Proc. Second Glacier Bay Sci. Symp. (eds Milner, A. M. and Wood, J. D. Jr) 127-132 (National Park Service, Anchorage, 1990)

36. McBride, M. S., and Pfannkuch, H. O. The distribution of seepage within lakebeds. US Geol. Survey J. Res. 3, 505-512 (1975).

37. Olson, O. G. Mechanisms of Long-term change in Periphytic diatom community structure. Thesis, Lehigh Univ. (1998).

38. Olson, O. G., Engstrom, D. R., and Fritz, S. C. in Proc. Third Glacier Bay Sci. Symp. 1993 (ed. Engstrom, D. R.) 154-163 (National Park Service, Anchorage, 1995).

39. Williamson, C. E., et al. Ultraviolet radiation and zooplankton community structure following deglaciation in Glacier Bay, Alaska. Ecology (in press).

40. Mann, D. H., and Ugolini, F. C. Holocene glacial history of the Lituya District, southeast Alaska. Can. J. Earth Sci. 22, 913-928 (1985).

41. Engstrom, D. R., Hansen, B. C. S., and Wright, H. E. Jr A possible Younger Dryas record in southeastern Alaska. Science 250, 13831385 (1990)

42. Winter, T. C., LaBaugh, J. W., and Rosenberry, D. O. The design and use of a hydraulic potentiomanometer for direct measurement of differences in hydraulic head between groundwater and surface water. Limnol. Oceanogr. 33, 1209-1214 (1988).

43. Birks, H. J. B., Line, J. M., Juggins, S., Stevenson, A. C., and terBraak, C. J. F. Diatoms and pH reconstruction. Phil. Trans. R. Soc. Lond. B 327, 263- 278 (1990).

44. Juggins, S., Flower, R. J., and Barrarbee, R. W. Palaeolimnological evidence for recent chemical and biological changes in UK Acid Waters Monitoring Network sites. Freshwat. Biol. 36, 203219 (1996) 